\title{
SURVEY OF SURGEONS' USE, ASSESSMENT AND LOOK-AHEAD OF ENDOSCOPIC SURGICAL TECHNOLOGIES
}

\author{
C.L. MacKenzie and J.A. Ibbotson* \\ Simon Fraser University \\ Burnaby, British Columbia, CANADA \\ Email: christine_mackenzie@sfu.ca
}

\begin{abstract}
A questionnaire soliciting the experience and opinions of surgeons of different specialties regarding Minimally Invasive Surgery (MIS) was used to gauge the present and future state of MIS. The questionnaire was sent to over 1000 surgeons in the province of British Columbia, Canada. Results are summarized, highlighting different aspects of MIS including demographics, procedures performed, constraints and possible solutions for the constraints of the surgical procedures performed by general and specialty surgeons. The look-ahead reveals the attitudes of surgeons toward future technologies and techniques.
\end{abstract}

\section{INTRODUCTION}

Technologies for image-guided surgery, endoscopic surgery and Minimally Invasive Surgery (MIS) are rapidly evolving. As technology advances and surgeons ${ }^{t}$ attitudes change, a fertile environment arises for the growth of minimally invasive surgical techniques in many different surgical specialties. There is a great deal of speculation as to the dynamics and interactions among different surgical specialties in the future. Further, there are important implications for technology development, new procedures and surgical training. (Ko, Whang, Karamoukian, Longmire, \& McFadden, 1998; Varghese, Patel \& Varghese, 1999; Wiegelt, Brasel, Olson, \& Thal, 1998).

In the last five years, we examined general surgeons learning and performing specific laparoscopic procedures, and the technology used in this MIS surgery using a triangle approach, studying the interaction of user-tool-task in the environment of the operating room (OR). To extend this surgeoncentered research on remote manipulation in laparoscopic surgery (Cao, MacKenzie \& Payandeh, 1996; Ibbotson, MacKenzie, Cao \& Lomax, 1999; MacKenzie, Graham, Cao \& Lomax, 1999; MacKenzie, Ibbotson \& Lomax, 2000), this report addresses a survey of surgeons from diverse surgical specialties. Surgeons reported their use, experiences, assessment and future use of MIS technologies.

\section{METHOD}

\section{Subjects}

In July, 1998, we surveyed 1008 general and specialty surgeons in British Columbia, Canada. These included academic (university) surgeons and community surgeons. All were listed in the 1997 Royal College of Physicians and Surgeons Directory of practising surgeons in British Columbia, Canada.

\section{Questionnaire, mailout, and followup}

A three page questionnaire was designed to assess demographics, procedures performed, difficulties and constraints in using current technologies for these procedures. As well, we asked surgeons to suggest ways of alleviating constraints through new technologies. Finally, we asked surgeons to report their attitudes towards issues in telemedicine, remote surgery, and virtual and augmented environments for surgical training. There were nineteen questions, primarily closed-ended, with some open-ended questions and opportunities. The questionnaire was pretested and iterated with feedback from 13 surgeons outside of British Columbia.

Two mailouts were sent: an initial mailout, and a followup to nonresponders. The mailout consisted of: a cover letter explaining the research goals, 
sponsors, and requesting input from the surgeons; a questionnaire; a postage-paid addressed envelope for the questionnaire; and a postage-paid addressed postcard with identifier to indicate that anonymous return of the questionnaire had been completed under separate cover, and to indicate interest in followup. A second package was mailed in October, 1998 to surgeons who had not yet responded. Returned questionnaires were coded to preserve confidentiality and anonymity of respondents.

\section{RESULTS}

\section{Response rate and demographics}

Overall, there was a 34 percent response rate; 343 surgeons responded in some way. Of these, 250 questionnaires were detailed enough for subsequent analyses. Of the 343 surgeons who responded, 73 (21 percent) requested followup contact.

The average age of surgeons was 48 (range: 31 81) years. Females comprised 9 percent and males 87 percent of respondents (4 percent did not answer). On average, the surgeons had been practising surgery for 17 (range: 2-50) years, with 9 $(0.5-37)$ of those years practising endoscopic surgery.

Of the respondents, there were 63 general, 47 ob/gyne, 45 orthopaedic, 31 ophthalmologic, and 17 otolaryngeal surgeons. The remaining surgeons practised in other specialties.

The surgeons performed an average of 150 (range: 2-1000) endoscopic procedures per year, spending approximately 164 (2-2000) hours per year on these procedures. Overall, of these 150 procedures, 27 percent $(0-100)$ were performed for diagnostic purposes, with intent to look only at the internal body environment. The remaining 73 percent (1-100) of procedures were done for therapeutic reasons. Here, the surgeons would look, repair, and manipulate the tissues to accomplish their surgical goal. The proportion of diagnostic and therapeutic procedures varied across surgical specialties. For example, 66 percent of urology procedures reported were for diagnostic purposes alone. In contrast, about half of the operations were diagnostic, and half were therapeutic for $\mathrm{ob} /$ gynecological and otolaryngeal procedures.

\section{Constraints and difficulties}

Most of the surgeons from various specialties had tool/technology complaints at the top of their list of constraints. In response to questions about the constraints and difficulties, more than $20 \%$ of the surgeons checked the following factors listed as possible constraints: equipment inconsistency, tools awkward to use, tools inadequate, poor image quality, limited field of view, lack of touch feedback, and technical knowledge of OR staff.

There were also constraints unique to each specialty, and to procedures within the specialties. For example, a small internal working environment was identified as a particular constraint by orthopaedic surgeons ( 24 percent), neurosurgeons (22 percent), and otolaryngologists (29 percent). Surgeons added to the list of constraints, lack of time and money in the OR.

Surgeons also reported that the most common reasons for converting to open surgery during an endoscopic procedure included: loss of visual field due to bleeding or adhesions, uncontrolled bleeding, acute inflammation, technical difficulties, injury to specific tissues, and drastic complications.

\section{Procedures: Difficulty and effectiveness of tools}

By surgical specialty, we identified for each reported procedure, the surgeons' ratings of the difficulty of the procedure, as well as their assessments of effectiveness of the tools they used for manipulation and visualization. Surgeons ranked these on a Likert scale of 1-7. For procedure difficulty, 1 was easy and 7 was difficult. For effectiveness of tools, 1 was effective and 7 was not effective. Table 1 highlights results for a subset of frequently performed or more difficult procedures.

Table 1 shows, for example, of the 63 general surgeons, 53 performed cholecystectomies, but only 10 surgeons performed fundoplications. For general surgeons, the more difficult procedures included fundoplications and bowel resections; effectiveness of tools was rated poorest for bowel resection by the 4 general surgeons who performed this procedure. Note the variation in ranked difficulties and effectiveness of tools within each surgical specialty. Ratings of less effective tools were usually associated with more difficult procedures. 
Table 1. Procedures by specialty, with surgeons' ratings of difficulty and effectiveness of tools, along with frequency of the procedure and the amount of time spent in a year performing that procedure.

\begin{tabular}{|c|c|c|c|c|c|c|}
\hline $\begin{array}{l}\text { Specialty } \\
\text { Procedure }\end{array}$ & $\begin{array}{c}\text { \# of } \\
\text { Surgeons }\end{array}$ & $\begin{array}{c}\text { Procedures } \\
\begin{array}{c}\text { /year } \\
\text { mean } \\
\text { (range) }\end{array} \\
\end{array}$ & $\begin{array}{l}\text { Duration } \\
\text { Hours } \\
\text { /year }\end{array}$ & $\begin{array}{c}\text { Difficulty } \\
\text { of } \\
\text { operation } \\
(1-7)\end{array}$ & $\begin{array}{c}\text { Effectiveness } \\
\text { of tools for } \\
\text { manipulation } \\
(1-7)\end{array}$ & $\begin{array}{c}\text { Effectiveness } \\
\text { of tools for } \\
\text { visualization } \\
(1-7) \\
\end{array}$ \\
\hline \multicolumn{7}{|l|}{ General Surgery } \\
\hline Cholecystectomy & 53 & $\begin{array}{c}70 \\
(12-200)\end{array}$ & $\begin{array}{c}60.9 \\
(30-90)\end{array}$ & 3.0 & 2.9 & 2.6 \\
\hline $\begin{array}{l}\text { Inguinal Hernia } \\
\text { Repair }\end{array}$ & 21 & $\begin{array}{c}48 \\
(6-125)\end{array}$ & $\begin{array}{c}51.8 \\
(30-90)\end{array}$ & 3.3 & 2.8 & 2.6 \\
\hline Fundoplication & 10 & $\begin{array}{c}18 \\
(2-30)\end{array}$ & $\begin{array}{c}129.2 \\
(100-180)\end{array}$ & 5.4 & 3.8 & 3.3 \\
\hline Bowel Resection & 4 & $\begin{array}{c}10 \\
\text { (no range) }\end{array}$ & $\begin{array}{c}180.0 \\
\text { (no range) }\end{array}$ & 6.0 & 6.0 & 6.0 \\
\hline \multicolumn{7}{|l|}{ Obstetrics/Gynecology } \\
\hline Tubal Ligation & 26 & $\begin{array}{c}83 \\
(2-300)\end{array}$ & $\begin{array}{c}20.5 \\
(5-35)\end{array}$ & 1.4 & 1.9 & 1.5 \\
\hline Endometriosis & 18 & $\begin{array}{c}47 \\
(5-100)\end{array}$ & $\begin{array}{c}52.8 \\
(20-120)\end{array}$ & 3.9 & 2.7 & 1.7 \\
\hline $\begin{array}{l}\text { Ovarian } \\
\text { Cystectomy }\end{array}$ & 13 & $\begin{array}{c}20 \\
(5-50)\end{array}$ & $\begin{array}{c}77.1 \\
(45-120)\end{array}$ & 4.3 & 3.7 & 3.0 \\
\hline \multicolumn{7}{|l|}{ Orthopaedic Surgery } \\
\hline Arthroscopic Knee & 42 & $\begin{array}{c}94 \\
(1-400)\end{array}$ & $\begin{array}{c}62 \\
(12-150)\end{array}$ & 3.8 & 3.2 & 2.9 \\
\hline Menisectomy & 18 & $\begin{array}{c}113 \\
(15-300)\end{array}$ & $\begin{array}{c}36 \\
(15-75)\end{array}$ & 3.5 & 3.7 & 3.7 \\
\hline $\begin{array}{l}\text { Shoulder } \\
\text { Arthroscopy }\end{array}$ & 14 & $\begin{array}{c}35 \\
(2-150)\end{array}$ & $\begin{array}{c}67 \\
(40-105)\end{array}$ & 4.7 & 4.0 & 3.2 \\
\hline Elbow Arthroscopy & 5 & $\begin{array}{c}14 \\
(5-40)\end{array}$ & $\begin{array}{c}51 \\
(30-70)\end{array}$ & 5.4 & 4.0 & 4.0 \\
\hline $\begin{array}{l}\text { Neurosurgery } \\
3^{\text {rd }} \\
\text { Ventriculostomy }\end{array}$ & 5 & $\begin{array}{c}5 \\
(2-10)\end{array}$ & $\begin{array}{c}69 \\
(45-120)\end{array}$ & 3.0 & 3.8 & 2.8 \\
\hline Cystoscopy & 2 & $\begin{array}{c}2 \\
\text { (no range) }\end{array}$ & $\begin{array}{c}90 \\
(60-120)\end{array}$ & 4.0 & 4.5 & 4.5 \\
\hline \multicolumn{7}{|l|}{ Otolaryngology } \\
\hline Ethmoidectomy & 11 & $\begin{array}{c}42 \\
(6-100)\end{array}$ & $\begin{array}{c}72 \\
(35-120)\end{array}$ & 5.4 & 3.4 & 3.5 \\
\hline Sinus Surgery & 9 & $\begin{array}{c}47 \\
(6-100)\end{array}$ & $\begin{array}{c}51 \\
(12-120)\end{array}$ & 3.7 & 2.8 & 2.9 \\
\hline
\end{tabular}




\section{TOWARD SOLUTIONS}

To alleviate constraints, surgeons recommended improved instrumentation, changes in techniques, education of OR staff, as well as increased organization and efficiency in the operating room environment. Tool development suggestions included: smaller and more flexible instruments, reusable tools and retractors, tools with force feedback, improved organ retractors, instruments that "see" what they are grasping and manipulating, and suction devices that suck up blood only, not fat.

By specialty, general surgeons suggested: crushers for gallstones, and abdominal wall elevating devices (e.g., gasless laparoscopy). Neurosurgeons requested improved methods for coagulation and bleeding control. Orthopaedic surgeons requested: improved shavers for smoothing surfaces, refined techniques for articular cartilage transplant or cultures, and a foreign body disintegrator. Surprisingly, technologies predicted in the future to alleviate constraints by some surgeons were already in use by other surgeons, in the same or other specialties.

\section{TECHNOLOGY LOOK-AHEAD}

Looking to the future, on average, most surgeons were comfortable with new technologies that may improve their surgical skills as well as the surgical procedure and patient outcome. Again, we had them rank their comfort level on a scale of $1-7$ with various technologies and future possibilities. Surgeons reported they were very comfortable with the use of robotic static holders and image-guided active tissue holders. They were relatively uncomfortable with glues for approximating tissues, compared to staplers and automatic suturing devices. A larger proportion of surgeons reported being comfortable with combined visualizationmanipulation systems for augmented reality environments for training than were comfortable using such systems for automated surgical assistance. Concerning telemedicine, it appeared that surgeons were comfortable with remote consultation regarding patients and telelearning for surgical procedures, but were relatively less comfortable with telesurgery. That is they were not very comfortable with remote guidance of surgery or remote execution of surgical procedures.

Evolving surgical and computer technologies are rapidly changing the context for minimally invasive surgery. Such evolution should be informed and driven by the users' needs.

\section{ACKNOWLEDGEMENTS}

Supported by grants to C.L. MacKenzie from the B.C. Health Research Foundation, and the Canadian Institute for Robotics and Intelligent Systems (IRIS3), Intelligent Tools for Health Care project.

*J.A. Ibbotson, now a graduate student in Human Kinetics at the University of British Columbia, was supported also by a Natural Sciences and Engineering Research Council of Canada Undergraduate Research Award.

\section{REFERENCES}

Cao, C.G.L., MacKenzie, C.L., Payandeh, S. (1996). Task and motion analysis in endoscopic surgery. In DSC-VOL58, Proceedings of the ASME Dynamic Systems and Controls Division, 583-590.

Cao, C.G.L., MacKenzie, C.L., Ibbotson, J.A., Tumer, L.J., Blair, N.P. \& Nagy, A.G. (1999). Hierarchical decomposition of laparoscopic procedures. In Westwood, J.D., Hoffman, H.M., Robb, R.A., \& Stredney, D. (Eds.), Medicine Meets Virtual Reality 7. The Convergence of Physical and Informational Technologies: Options for a New Era in Healthcare). Amsterdam: IOS Press, 83. 89.

Ibbotson, J.A., MacKenzie, C.L., Cao, C.G.L., \& Lomax, A.J. (1999). Gaze patterns in laparoscopic surgery. In Westwood, J.D., Hoffman, H.M., Robb, R.A., \& Stredney, D. (Eds.), MMVR7. The Convergence of Physical and Informational Technologies: Options for a New Era in Healthcare. Amsterdam: IOS Press, 154-160.

Ko, C.Y., Whang, E.E., Karamanoukian, R., Longmire, W.P., and McFadden, D.W. (1998). What is the best method of surgical training? Archives of Surgery Vol. 133, 900-905.

MacKenzie, C.L., Graham, E.D., Cao, C.G.L., \& Lomax, A.J. (1999). Virtual hand laboratory meets endoscopic surgery. In Westwood, J.D., et al. (Eds.), MMVR 7. The Convergence of Physical and Informational Technologies: Options for a New Era in Healthcare. Amsterdam: 1OS Press, 212-218.

MacKenzie, C.L. Lomax, A.J. and Ibbotson, J.A. (2000). Safety and error issues in minimally invasive surgery. In M.S. Bogner (Ed.), Human Error in Health Care. Mahwah, N.J.: Lawrence Erlbaum, in press.

Sheng, O.R.L., Hu, P.J., Chau, P.Y.K., Hjelm, N.M., Tam, K.Y., Wei, C., \& Tse, J. (1998). A survey of physicians' acceptance of telemedicine. Journal of Telemedicine and Telecare; 4(1): 100-102. Varghese, D., Patel, H., and Varghese, A. (1999). Surgical training for the next millennium. Hospital Medicine 60, (3), 210-211.

Wiegelt, J., Brasel, K. Olson, C and Thal, E. (1998). Opinions of practicing general surgeons on surgical education. American $J$. Surgery, 176, 481-485. 